\title{
HOW DO SLOVAK SMALL AND MEDIUM-SIZED ENTERPRISES MAKE DECISION ON SOURCES OF FINANCE?
}

\author{
Miroslava Vinczeova ${ }^{1, a, *}$, Alena Kascakova ${ }^{2, b}$ \\ ${ }^{1}$ Matej Bel University in Banská Bystrica, Faculty of Economics, Department of Business Economics \\ and Management, Slovak Republic \\ ${ }^{2}$ Matej Bel University in Banská Bystrica, Faculty of Economics, Department of Quantitative Methods \\ and Information Systems, Slovak Republic \\ amiroslava.vinczeova@umb.sk, balena.kascakova@umb.sk \\ *Corresponding author
}

Cite as: Vinczeova, M., Kascakova, A. (2017). How do Slovak small and medium-sized enterprises make decision on sources of finance? Ekonomicko-manazerske spektrum, 11(2), 111-121.

Available at: dx.doi.org/10.26552/ems.2017.2.111-121

\begin{abstract}
The traditional financial theory generally presents models and approaches applicable mostly in financial management of large enterprises. Small and medium-sized enterprises are characterized by a number of specific features, which significantly differentiates them from large ones and determinates their limited access to appropriate sources of finance. In light of these differences and specific features, it is essential to draw particular attention to the decisionmaking on sources of finance in these enterprises which have a more risky profile and are much more vulnerable to the business environment and its changes. The paper focuses on the target debt ratio of Slovak small and medium-sized enterprises and its relationship with their superior business objective, size and age. It also examines the factors influencing this area of decisionmaking. The main aim of the paper then is to find out how Slovak small and medium-sized enterprises make decisions on sources of finance to perform their business activities and identify the main factors influencing these decisions. According to the results obtained, half of Slovak small and medium-sized enterprises have set the target debt ratio. It is more present in enterprises tending to prefer growth and development as their superior goal. The weak positive relationship between the existence of the target debt ratio and the size of an enterprise was also revealed. However, the existence of the target debt ratio is not determined by the age of an enterprise. Finally, the most important factors influencing financial decision-making of Slovak small and medium-sized enterprises include cost of capital and their long-term survival.
\end{abstract}

Keywords: sources of finance, small and medium-sized enterprises, target debt ratio, factors influencing decision on the structure of sources of finance, cost of capital

JEL Classification: G30, G39, L21, O16

\section{Introduction}

Given that the structure of sources of finance under modern approaches to the financial theory directly affects the market value of a company, decision making on it is important and is currently receiving much attention in many scientific studies and research. The traditional financial theory, however, encounters a rather fundamental problem - it presents approaches that are generally applicable mainly to financial management of large enterprises, their 
applicability in smaller ones is more or less limited. Small and medium-sized enterprises (hereinafter referred to as SMEs) are characterized by a number of specific features that distinguish them from large enterprises and determine their different access to necessary capital, as opposed to large enterprises. These enterprises that make up a backbone of any economy are faced with multiple constraints in their financial decision-making. It is therefore necessary to examine their decision-making on sources of finance, taking into account their differences and specificities. Hence, we decided to focus our attention of the decision-making relating to the choice of sources of finance in Slovak SMEs. The aim of the paper is to find out how Slovak SMEs decide on the sources of financing their activities, and identify the main factors influencing their decision-making. The paper is structured as follows. The next section develops the theoretical framework used for the analysis providing a review of the literature on the subject. The section three describes the methodology used for this study. It presents the hypotheses and explains methods used for their verification. The section four presents the main results and the section five interprets, discusses and summarizes the findings of the research.

\section{Decision on sources of finance in small and medium-sized enterprises}

Financial decision-making on obtaining sources of finance in terms of acceptable risk and capital structure optimization belongs to financial decisions with long-term effects on the overall situation of a company and is an integral part of modern financial management. Sivak and Mikocziova (2006) Financial management concerns on how to make the best decisions on the way to excellence of business processes, mainly regarding the company`s value enhancement (Hiadlovsky et al., 2016) which is considered the superior business as well as financial goal by the modern financial theory. In the real world it is necessary to respect a great many market frictions, which makes structure of sources of finance matter very much (Bodie et al., 2009), as they are limited in a business. Current approaches to financial theory consider the importance of the structure of sources of finance to meet the highest financial objective of maximizing the market value as a key. Brigham and Houston (2012), like many other authors, directly link the capital structure with business value maximization. They argue that the optimal capital structure is such a combination of debt and equity of a business, which maximizes its internal value. Because of its unquestionable importance, decision on sources of finance and thinking about the factors influencing it have in the long run been the subject of many scientific debates and researches trying to find a way to capital structure optimization.

There are many theoretical approaches to capital structure. Their aim is to find answers to riddles and uncertainties about its optimization. They provide a financial manager with some helpful clues, however, compared to theoretical concepts, the situation in real financial markets, which are not perfect, is much more complex, intricate and is affected by many more factors than only those taken into account in the particular theoretical concepts of capital structure. Baker et al. (2011) state that current capital structure theories can not adequately explain the decision-making on sources of finance in business practice. Many studies and analyses carried out so far show little balance between theoretical approaches and business practice. Instead, their results show that businesses do not rely on theoretical principles but rather on the rule of thumb. This approach is explicitly or implicitly described in scientific studies, the results of which were monitored over a 30-years` period. Baker et al. (2011) Similarly, Graham and Harvey (2001) claim that financial managers, when deciding on sources of finance, are less closely following the factors and theories described in the academic literature. According to them, the two most important factors influencing financial decisions are the financial flexibility and maintaining creditworthiness of a business. Despite this consensus, some authors disagree 
that such an approach explains the capital structure decision in business practice and claim that the dominant rule in realistic decision-making is the heuristic approach. Baker et al. (2011) Graham and Harvey (2001) have shown in their research a certain, though relatively weak, consensus with the compromise capital structure theory. They identified the relationship between the existence of the target debt and the firm size, when some target debt ratio was set in 55 per cent of large enterprises but only in 36 per cent of small enterprises. However, most small business owners do not specify their target financial structure. They prefer sources of capital eliminating third party involvement in their business, particularly internal equity and, after its exhausting, short-term debt followed by long-term loans. External sources in a form of new investors are only used as a last choice (Hamilton \& Fox, 1998), which is in line with the pecking order theory. As can be seen, the capital structure policy differs across firm size ranges (Graham \& Harvey, 2001) and a large number of enterprises do not even consider capital structure optimization. They include, in particular, smaller enterprises where the practical application of theoretical principles is to a large extent limited and often struggle for any available sources of finance. Compared to large enterprises, they have more limited funding options, which consequently greatly reduces the scope for decision-making on their structure. (Kalusova \& Kubricanova, 2014) Joeveer (2013) points to the need to distinguish the debt share depending on the firm size, and also on whether a company is public or private. SanfilippoAzofra et al. (2016) also mention some other limitations of previous studies. Many, for example, analysed only the capital structure of healthy businesses, however, their results are not fully applicable in businesses under financial distress. It follows unequivocally that reaching the target capital structure, which is at the same time optimal, is a complex task in business practice. A wrong decision may have fatal consequences for the enterprise, not only for its further development but even for its own survival. (Bubic \& Susak, 2015) Due to the increased vulnerability of SMEs, this is especially true for this business segment.

Decisions on the proportion of equity to debt are influenced by a number of factors. Cost of capital is often considered the most important of them. This is related to the fact that debt is usually regarded cheaper than equity and its use leads to the cost of capital minimization, and should therefore contribute to the business value maximization. The use of this capital is linked to a leverage risk endangering the business financial stability. Kalusova and Fetisovova (2015) argue that, during the last financial and economic crisis, enterprises which used substantially more equity than debt were financially more stable. Similarly, based on the financial data of Italian SMEs in 2008 - 2010 (i. e. during the ongoing financial crisis), Dezi and Del Guidice (2014) found that businesses that preferred self-financing over that period showed, on average, positive results in contrast to businesses using debt, particularly bank loans, whose results were, on average, negative. Zhang et al. (2014) came to the conclusion that, unlike theoretical approaches, the cyclical development has a great influence on the capital structure determination in the real economy. During the financial crisis, there is a decline in target debt, which is particularly pronounced in small enterprises without stable cash flows, in private enterprises compared to state ones, and in enterprises which do not have high-quality assets to guarantee for a loan. That can mean, especially during the financial crisis, that the cost of capital may not be a key factor in sources of finance decision. Even Graham and Harvey (2001) do not see the cost of capital as the most significant criterion of forming a financial structure. They consider financial flexibility as the most important factor and include the creditworthiness, cash flow volatility, tax advantage resulting from the possibility to reduce the tax base by interest, transaction cost associated with the securities issue, the industry indebtedness, potential cost of financial distress, debt reduction so that the financial situation of the business does not negatively affect customers and suppliers, debt reduction so that returns on investment projects 
can be fully distributed to the owners, effort to use more debt so that the business does not become a takeover target, and some other factors. Bancel and Mittoo (2004) found in their research in 2001 - 2002 that up to 75 per cent of European businesses had a target debt ratio. They also found that the most important factor was maintaining business financial flexibility. Like the Anglo-Saxon companies examined by Graham and Harvey (2001), as well as European businesses also identified the following most important factors including creditworthiness, tax advantage and cash flow volatility. (Baker et al., 2011) Some other authors as Vlachynsky and Kralovic (2011); Vinczeova and Kristofik (2013); Fetisovova et al. (2014) mention the cost of capital, leverage risk, financial certainty and freedom, ownership structure and control, expected cash flows and their stability, tax position, managers`approach towards the risk, capital market conditions and transaction costs, rate of inflation, dividend policy, characteristics and type of the industry in which the business operates, business life cycle, etc., as the most important factors influencing the capital structure decision. The financial structure is also closely linked to the assets structure. Their mutual relationship is reflected in the financial situation of the business, particularly in its solvency and liquidity. Several authors confirm that the availability of sources of finance is greatly affected also by the firm size (for example, Rajan \& Zingales, 1995; Bessler et al., 2011). This, together with the firm age, also determines the perception of capital availability. Microenterprises and the youngest enterprises (less than 10 years old) perceive it worse than other size categories of businesses. The perceived availability of funding is also linked to the dynamics of business development. The growing enterprises (in terms of the growing number of employees, cash flows and investment volume) perceive capital availability to be better than those that do not grow. (Canton et al., 2013)

Many SMEs are dependent on external sources of finance. But as a result of information asymmetry for which outsiders have the worse access to information, they are often not able to obtain them. Nangaki et al. (2014) Small and young enterprises often owned by their founders, with a short history and higher riskiness face the most limited access to sources of finance (Levenson \& Willard, 2000; Rajan \& Zingales, 1995). Rahman et al. (2017) in the context of the information asymmetry even talk about credit discrimination of SMEs by banks. The likelihood that larger and older enterprises will obtain necessary sources of finance, especially bank loans, is higher. It is obvious that information asymmetry significantly restricts mainly the opportunities of the debt use in SMEs, which is, in addition to the abovementioned authors, confirmed by many others (for example, Hamilton \& Fox, 1998; Petersen \& Rajan, 2002; Mason \& Stark, 2004; Canton et al., 2013; Moro et al., 2015).

SMEs are characterized by certain typical features, including low capital strength, lack of suitable assets for the purpose of collateral, unstable financial situation (particularly unstable cash flows) and inappropriate capital structure, low diversification degree, increased vulnerability to business risk and financial risks, insufficient reporting and financial plans, high share of wages in total costs, short history of starting businesses, insufficient professional competences and managerial skills. These and several other characteristics are a source of funding disparities between SMEs and large enterprises. SMEs are more risky clients, therefore they face many barriers in the access to capital. Their existence results in the so called financing gap reflected in financial market failures in funding businesses which are clearly viable, nevertheless their financial needs are not met. SMEs in Central Europe show a lower debt ratio than their counterparts in Western Europe, which is a sign of the financial gap. The lower debt use in Eastern Europe does not arise from the lower businesses interest, but from the worse debt accessibility. (Jensen \& Meckling, 2008; North et al., 2010) Limited funding opportunities of SMEs resulting from the financial gap are also confirmed by a lot of other authors (for 
example, Rajan and Zingales (1995); Levenson and Willard (2000); Hyytinen and Pajarinen (2008); Majumdar (2014), Musa et al. (2016), et al.).

Some of the above specifics and financing barriers force SMEs, as mentioned above, to rely heavily on external sources of finance. The scope of their use is historically also determined by macroeconomic corporate governance systems, i. e. the Anglo-Saxon, continental or Japan system. The Anglo-Saxon system is particularly present in the USA and Great Britain. It is dominantly market-oriented and enterprises obtain a large share of their capital through the issue of securities on the developed capital market. Loan financing offered by banks is less significant. The Japan system is applied in Asian countries. There is a typical existence of special clusters of independent enterprises owned by a closed group of shareholders with coordinated internal relationships. Unlike the Anglo-Saxon system, the bank-oriented continental system is characterized by a lower share of capital acquired through the issue of securities and higher ownership concentration due to the less developed capital market. Debt financing mainly includes financing through bank loans. The share of debt raised by the issue of bonds is rather small. Banks thus have a relatively strong controlling influence in businesses. The strong market position of banks, especially in such systems, often results in higher interest rates and the more restricted access to credit for SMEs. (Ryan et al., 2014) The country or region factors are neglected by the majority of capital structure theories. However, its importance, particularly in the field of external financing, is indisputable. (Kalusova \& Fetisovova, 2015) Joeveer (2008) also finds the country factor important in explaining business indebtedness. She argues that it is a significant determinant of decision-making on sources of finance, in particular in small and private businesses that do not raise capital through the public capital market.

\section{Methodology}

The main aim of the paper is to find out how Slovak small and medium-sized enterprises make decisions on sources of finance to perform their business activities and identify the main factors influencing these decisions. Following this objective, we formulated four hypotheses. In the section 2, we stated that 75 per cent of European enterprises had determined their target debt ratio. Bancel and Mitoo (2004) This value involves all enterprises. As we also stated, larger enterprises were more systematically involved in capital structure decision as the target debt ratio was set by 55 per cent of large enterprises, but only by 36 per cent of small ones. Graham and Harvey (2001) As our research is focused on SMEs, we do not expect the share of those with the set target debt ratio to be so high as that one of all enterprises having the target debt in the Bancel and Mittoo's research (2004), nor so low as the share of small enterprises with the target debt in the Graham and Harvey`s research (2001). Based on these findings, we decided to formulate Hypothesis 1 as follows:

H1: We assume that half of Slovak SMEs have set the target debt ratio.

We used the binomial test to verify Hypothesis 1 . In our research, we focus on determining what the superior business objective of Slovak SMEs is and whether they have set their target debt ratio. If managers take decisions in accordance with a certain enterprise-wide objective, we assume that such target-oriented behaviour in many businesses also involves setting a target debt ratio. Therefore, we formulated the following Hypothesis 2:

H2: We assume that there is a direct relationship between the existence of the target debt ratio of the enterprise and its main business objective.

To verify Hypothesis 2, we used the correlation analysis. The existence of the relationship was verified by the Spearman correlation coefficient. As mentioned above, several researches dealt with the relationship between the existence of the target debt ratio and firm size. We think 
that other factors also influence monitoring of the target debt ratio. We were interested whether there was the relationship between the existence of the target debt ratio and firm size in the Slovak SMEs, but we also focused on their age. We formulated Hypothesis 3 as follows:

H3: We assume that there is a direct relationship between the existence of the target debt ratio of the enterprise and its size and age.

To verify the hypothesis, we used the correlation analysis. The existence of the relationships was verified by means of the Spearman correlation coefficient. In the Section 2, we presented an overview of different authors' views on the most important factors affecting business decision-making on sources of finance. We can see that these views are not consistent. Since, especially in our literature (for example, Vlachynsky \& Kralovic, 2011; Vinczeova \& Kristofik, 2013; Fetisovova et al., 2014), the cost of capital is often considered the most important factor, we decided to verify this argument in Slovak SMEs and we formulated Hypothesis 4 as follows:

H4: We assume that the most important factor influencing the decision-making on sources of finance in Slovak SMEs is the cost of capital.

The hypothesis was verified by means of the Friedman test and Wilcoxon test. By means of the Friedman test, we found out whether there were significant differences between the perceived importances of factors. Using the Wilcoxon test, we tested, in pairs, the statistical significance of differences in the perceived importance of particular factors, and we set the order of perception of their importance.

All hypotheses were tested at the 5 per cent level of significance $(\alpha=0.05)$. We used the statistical software IBM SPSS v. 19 for testing. The data needed to determine how the Slovak SMEs decide on the structure of sources of finance and to identify the factors that most influence their decision-making were obtained through the questionnaire survey, which was carried out in October to December 2016. An electronic questionnaire was sent to Slovak SMEs based in the Slovak Republic. The sample consisted of 932 Slovak SMEs. In accordance with the results of the Chi-squared test of homogeneity, it is representative in terms of the firm size ( $\mathrm{p}$-value $=0.557)$ and in terms of their legal form for the distinction between physical and legal entities $(\mathrm{p}$-value $=0.503)$.

\section{Results}

When asked whether they had set the target debt ratio, the enterprises could choose four possible answers: (1) zero target debt, (2) specific exact debt higher than 0 per cent, (3) determined maximum debt as percentage, and (4) no target debt ratio. The choice of one of the first three options meant that the enterprise had determined the target debt ratio. The indication of the fourth option meant that the enterprise had no target debt ratio. In Hypothesis 1, we assume that half of Slovak SMEs have set the target debt ratio. It is clear from the results of the binomial test that it is not possible to reject the assumption that half of Slovak SMEs has set the target debt ratio ( $\mathrm{p}$-value $=0.578$ ), which confirms Hypothesis 1 .

In our survey research, we wanted to know what the main goal of businesses was for the next three years. Objectives such as growth (i. e. the growing market share, sales, etc.), maintained stability (i. e. maintaining at least the current state), survival (i.e. an effort to prevent imminent bankruptcy) could be chosen by enterprises as their main objective. Where appropriate, businesses could also present another main objective, however, these responses were excluded from the testing of Hypothesis 2. The existence of the target debt was assessed as described above. We assumed in Hypothesis 2 that there is a direct relationship between the existence of the target debt ratio of the enterprise and its main business objective. The results 
of the Spearman correlation coefficient test show that the relationship exists ( $\mathrm{p}$-value $=0.000$ ), however it is weak (0.118).

Our research sample includes small and medium-sized enterprises. The size of the enterprise is determined by the number of employees, with microenterprises having a maximum of 9 employees, small businesses with between 10 and 49 employees and medium-sized enterprises from 50 to 249 employees. The assessment of the firm age is based on the time since the business 'setting up. The options determining the age the businesses could identify were: (1) less than 3 years, (2) $3-7$ years, (3) 8 - 15 years, (4) more than 15 years. Hypothesis 3 assumed the direct relationship between the existence of the target debt ratio of the enterprise, its size and age. Using the Spearman correlation coefficient, we found that there was a weak direct relationship between the existence of the target debt ratio and the size of the enterprise (the Spearman correlation coefficient is 0.096). The relationship between the existence of the target debt ratio of the enterprise and its age was not statistically significant at the chosen level of significance. Therefore, we can only partially confirm Hypothesis 3.

Through the questionnaire survey, we asked enterprises to indicate the relative importance of the factors influencing them in deciding on the sources of finance and their structure. The individual factors could be assigned a score of 1 to 5,1 being an insignificant factor, 5 a very important one. In Hypothesis 4, we assumed that the most important factor in deciding on sources of finance in Slovak SMEs is the cost of capital. By means of the Friedman and Wilcoxon tests, we found that the differences in the assessment of particular factors were statistically significant. As the most important factor in deciding on sources of finance businesses identified the cost of capital as well as maintaining their long-term survival. The order of all factors is presented in Table 1.

\begin{tabular}{lll} 
Table 1: Order of importance of factors influencing decision-making on sources of finance in Slovak SMEs \\
\hline \multicolumn{1}{l}{ Order } & Factor & p-value \\
\hline 1. & cost of capital & - \\
& maintaining long-term survival & 0.269 \\
\hline 2. & risk of insolvency & 0.000 \\
& maintaining creditworthiness & 0.052 \\
\hline 3. & maintaining financial independence & 0.000 \\
& cash flow volume and stability & 0.147 \\
& maintaining financial flexibility & 0.755 \\
\hline 4. & ownership structure and control & 0.180 \\
\hline 5. & possible tax base reduction & 0.000 \\
\hline 6. & assets structure & 0.000 \\
& industry of operation & 0.000 \\
& situation on capital market & 0.071 \\
& inflation & 0.506
\end{tabular}

Source: Own elaboration

Based on the results presented in Table 1, Hypothesis 4 is partially confirmed, since, as the most important factor, the representatives of Slovak SMEs consider, apart from cost of capital, also maintenance of the long-term survival of their enterprise.

\section{Discussion}

The intention of our research was to find out how Slovak SMEs decide on the sources of finance structure, whether they have the set target debt ratio, wheter there is a link between its existence and the business objective, size and age of the enterprise. We also considered which 
the most important factors influencing decision-making on the sources of finance choice in Slovak SMEs were. We found that half of the Slovak SMEs set their target debt ratio. If, at the European level, the target debt ratio is set by 55 per cent of large enterprises and 36 per cent of small ones, our result representing SMEs` approach is in the interval determined by these two values. On the other hand, there is still a significant number of enterprises with no target debt ratio set. This does not have necessarily to mean that all these enterprises do not think about the structure of their sources of finance at all. Our finding means that they do not have a fixed percentage or some limit of their debt. Some of them may apply other principles of decisionmaking on sources of finance that are not based on the specific target debt. Business (counsciously or unconsciously) may take decisions in accordance with the pecking order theory or apply the heuristic approach, which, as we stated above, according to Baker et al. (2011) is the dominant rule of business practice. Though, it should be emphasized that enterprises should have at least a general idea of their capital structure, as only based on it they can take appropriate short-term as well as strategic financial decisions.

Our results show the weak direct relationship between the existence of the target debt ratio of the enterprise and its main business objective. In terms of possibilities to choose in describing the primary business objective, this result indicates that the target debt ratio is rather set by SMEs with a "more ambitious" business objective. This means that the more the business tends to focus on growth and development, the more likely it also is to behave purposefully when choosing its sources of finance. Such target-oriented behaviour can be assessed positive because it finally contributes to the fulfilment of the superior business objective that is currently considered to be owners` wealth maximisation respecting limitations given by other stakeholders. Whether an enterprise has set its debt ratio depends on various factors. We wanted to know whether the size and age of the business belonged among them. The relationship between the existence of the target debt ratio and firm size was confirmed by several foreign researches. We also identified the weak direct relationship in Slovak SMEs. From this we can see that the larger the businesses (in terms of the number of employees), the more they set their target debt ratio, although this relationship is only weak. We can only believe that in larger businesses the specialized, educated and probably more experienced managers are responsible for financial management. They may be more aware of the significance of deciding on the appropriate structure of capital, and therefore they are more focused on the target debt ratio. Larger businesses generally need more capital and their managers are likely to realize that wrong decisions about its structure can have catastrophic consequences for their enterprise. The results of our research in Slovak SMEs brought a surprising conclusion for us when they did not show any correlation between the existence of the target debt ratio of the enterprise and its age. Hence, it can not be assumed that the number of Slovak SMEs with the set target debt ratio will grow with their age.

In literature, we can find different views on which factors mostly influence decision-making on the structure of sources of finance in enterprises. Most authors, however, present these factors generally for all businesses. We were hereby interested in what factors are considered the most important by representatives of Slovak SMEs. Their order is shown in Table 1. As we assumed, the most important factor is the cost of capital. Generally, debt is less expensive than equity. Therefore, the lack of SMEs`access to this capital is a focus not only of the theory but also of competent authorities and institutions. In spite of the generally lower price of debt compared to equity, however, loan financing may be relatively expensive for some SMEs. The interest rate is also affected by such factors as the amount of a loan and its maturity, business risk, or business credit history which may make the loan more expensive. Traditional bank loans for SMEs are therefore often available under less favourable conditions, sometimes they are 
even completely unavailable. As seen in Table 1, the most significant factor, along with the cost of capital, is also the need to maintain the long-term survival of the enterprise. This leads us to believe that, when considering their sources of finance, businesses do not only consider their price as a short-term factor but also take into account the potential consequences of the chosen capital use for their future operation, and they consider whether a certain choice of capital can not be a threat for their future existence. The factors that rank second, namely the risk of insolvency and the maintainance of business creditworthiness, are also closely related. Accordingly, we can assume that it is important for businesses that the chosen sources of finance do not threaten their solvency and their choice also takes into account that their potential failure to meet their commitments will not damage their reputation and the capacity to obtain appropriate funding in the future. The third are the factors reflecting the effort of businesses to maintain their financial independence and flexibility, but also their ownership structure, and retention of the control over the business. In decision-making, the ability to generate and maintain an adequate volume and stability of cash flow is essential for businesses to be able to conduct their business smoothly while meeting their debt service obligations, or pay dividends to their owners. In Table 1, we can observe that the possible tax base reduction, assets structure, industry of operation, capital market situation, or inflation are among the less important factors and enterprises pay less attention to them than to other above mentioned factors. We stated that in the literature, views on the importance of individual factors were inconsistent. When comparing our results with those of the research presented in Section 2, we find that many foreign authors see the maintenance of financial flexibility the most important factor, and they also often include the maintenance of creditworthiness among the most important factors. Creditworthiness is also very important for Slovak SMEs (it is on the second place in the order of factors). Financial flexibility moved to the third place with some other factors. This may reflect a tighter situation in the availability of funding when Slovak SMEs are more interested in its cost and maintenance of their survival or solvency rather than their financial flexibility and independence. We think that the latter two factors are more important and interesting for businesses with the ready access to capital and higher financial strength.

As we have already pointed out, SMEs`access to capital is often limited. While in the AngloSaxon countries the capital market expands financing options of businesses, including SMEs, also by the issue of securieties, in our country, the underdeveloped capital market is another barrier that limits the financing options of our SMEs in several ways. Belonging to particular corporate governance systems thus predetermines the structure of sources of finance to a large extent. In bank-oriented Europe, therefore, bank loans dominate as a significant source of finance in the business sphere. But, SMEs face many barriers to their acquisition. The availability of sources of finance including bank loans is often aggravated by the information asymmetry, which may result in SMEs being able to obtain capital under worse conditions compared to large businesses. The existence of the information asymmetry also may negatively affect business creditworthiness. The information asymmetry can be limited to a certain extent through appropriate reporting, which should become a part of information policy that reinforces the reliability of actions for and relations with stakeholders, helps to manage reputation risks and build competitive advantage. Kristofik et al. (2016) This should apply not only to large enterprises but also to SMEs. The scope of reporting should, naturally, be tailored to the needs and capabilities of this size category of businesses. Sufficient access to sources of finance and their appropriate structure belong to the key prerequisites for business success, its competitiveness and sustainable development. Despite some improvements, many SMEs, including Slovak ones, still have to face barriers to raising capital, preventing them from full development of their growth potential. These enterprises are characterized by significant 
differences in comparison with large ones. Their decision on the choice of suitable sources of finance is therefore legitimately different from financial decision-making of large enterprises and therefore it is necessary to pay special attention to these issues also in scientific research.

\section{Conclusion}

In the paper we looked at the specificity of decision-making on sources of finance in SMEs paying special attention to those doing business and based in Slovakia. We focused on their target debt ratio and its relationship with the main business objective, but also on whether its existence in a business is determined by its size and age. We were also interested in the factors that most influence the business decisions on the sources of finance. We found out that half of Slovak SMEs set the target debt ratio, that it was set more by businesses with a more ambitious business objective with the tendency to develop and grow than businesses whose current goal is stabilization or their very survival, that the target debt ratio was set by more larger enterprises but its existence did not depend on the firm age, and that the most important factors influencing decision on the structure of sources of finance in Slovak SMEs were the cost of capital and maintenance of the long-term survival. These findings helped us to some extent clarify the businesses`approach to deciding on the structure of sources of finance and understand the most important factors influencing this decision-making process. SMEs, including Slovak ones, still struggle with the limited access to capital. Their primary criterion when thinking about it is its price and, at the same time, whether the choice will not endanger their future existence. It is therefore necessary to look for ways to make the capital more available to this business segment to ensure its development and support its competitiveness, since, without its long-term growth, no economy can successfully and sustainably grow and flourish.

\section{References}

Baker, H.K., Singleton, J.C. \& Veit, E.T. (2011). Survey research in corporate finance. Bridging the gap between theory and practice. Oxford, United Kingdom: Oxford University Press.

Bancel, F. \& Mittoo, U.R. (2004). Cross-country determinants of capital structure choice: A survey of European firms. Financial Management, 33(4), 103-132.

Bessler, W., Drobetz, W. \& Kazemieh, R. (2011). Capital structure and corporate financing decisions. Theory, evidence, and practice. Chapter 2 factors affecting capital structure decisions. Hoboken, New Jersey: John Wiley \& Sons, Inc.

Bodie, Z., Merton, R.C. \& Cleeton, D.L. (2009). Financial economics. $2^{\text {nd }}$ ed. Upper Saddle River, New Jersey: Pearson Prentice Hall.

Brigham, E.F. \& Houston, J. (2012). Fundamentals of financial management. $7^{\text {th }}$ ed. Mason, Ohhio: SouthWestern Cengage Learning.

Bubic, J. \& Susak, T. (2016). Detecting optimal financial and capital structure: the case of small and medium enterprises (SME) in Republic of Croatia. Journal of Economic and Social Development, 3(1).

Canton, E., Grilo, I., Monteagudo, J. \& Van Der Zwan, P. (2013). Perceived credit constraints in the European Union. Small Business Economics, 41(3), 701-715.

Dezi, L. \& Del Guidice, M. (2014). Economic performance and capital structure choices. International Studies of Management \& Organization, 44(1), 42-54.

Fetisovova, E., Nagy, L. \& Vlachynsky, K. (2014). Aktuálne trendy vo financiách malých a stredných podnikov. Bratislava, Slovak Republic: Vydavatel'stvo EKONÓM.

Graham, J.R. \& Harvey, C.R. (2001). The theory and practice of corporate finance: Evidence from the field. Journal of Financial Economics, 60(2-3), 187-243.

Hamilton, R.T. \& Fox, M.A. (1998). The financing preferences of small firm owners. International Journal of Entrepreneurial Behavior \& Research, 4(3), 239-248.

Hiadlovsky, V., Rybovicova, I. \& Vinczeova, M. (2016). Importance of liquidity analysis in the process of financial management of companies operating in the tourism sector in Slovakia: an empirical study. International Journal for Quality Research, 10(4), 799-812. 
Hyytinen, A. \& Pajarinen, M. (2007). Opacity of young businesses: Evidence from rating disagreements. Journal of Banking \& Finance, 32(7), 1234-1241.

Jensen, M.C. \& Meckling, W.H. (1976). Theory of the firm: Managerial behavior, agency costs and ownership structure. Journal of Financial Economics, 3(4), 305-360.

Joeveer, K. (2013). What do we know about the capital structure of small firms? Small Business Economics, 41(2), 479-501.

Kalusova, L. \& Fetisovova, E. (2015). Determinanty finančnej štruktúry slovenských malých a stredných podnikov. Ekonomický časopis, 63(3), 278-300.

Kalusova, L. \& Kubricanova, E. (2014). Výskum vplyvu faktorov determinujúcich finančnú štruktúru slovenských MSP. Trendy Podnikáni 2014. Recenzovaný Sborník Přispěvkủ Mezinárodní Vědecké Conference. Pilsen, Czech Republic.

Kristofik, P., Lament, M. \& Musa, H. (2016). The reporting of non-financial information and the rationale for its standardization. E+M, Ekonomie a Management, 19(2), 157-175.

Levenson, A.R. \& Willard, K.L. (2000). Do firms get the financing they want? Measuring credit rationing experienced by small businesses in the U.S. Small Business Economics, 14(2), 83-94.

Majumdar, R. (2014). The determinants of indebtedness of unlisted manufacturing firms in India. Management Research Review, 37(9), 833-854.

Mason, C.M. \& Stark, J.M. (2004). What do investors look for in a business plan? A comparison of investment criteria of bankers, venture capitalists and business angels. International Small Business Journal, 22(3), $227-$ 248.

Moro, A., Fink, M. \& Maresch, D. (2015). Reduction in information asymmetry and credit access for small and medium-sized enterprises. The Journal of Financial Research, 38(1), 121-143.

Musa, H., Strokova, Z. \& Musova, Z. (2016). Financing of Slovak small and medium sized enterprises in globalizing environment. Globalisation and Its Socio-economic Consequences. Proceedings of 16th International Scientific Conference. Rajecke Teplice, Slovak Republic, 1458-1465.

Nangaki, L., Namusonge, S.N. \& Wandera, R.W. (2014). Factors influencing access to debt finance by micro and small enterprises: A case of Chwele Township, Bungoma County. International Journal of Innovation and Scientific Research, 12(1), 70-93.

North, D., Baldock, R. \& Ekanem, I. (2010). Is there a debt finance gap relating the Scottish SMEs? A demandside perspective. Venture Capital. An International Journal of Entrepreneurial Finance, 12(3), 173-192.

Petersen, M.A. \& Rajan, R.G. (2002). Does distance still matter? The information revolution in small business lending. The Journal of Finance, 57(6), 2533-2570.

Rahman, A., Rahman, M. T. \& Belas, J. (2017). Determinants of SMEs finance: Evidence from three European countries. Review of Economic Perspectives - Národohospodářský obzor, 17(3), 263-285.

Rajan, R.G. \& Zingales, L. (1995). What do we know about capital structure? Some evidence from international data. The Journal of Finance, 50(5), 1421-1460.

Ryan, R.M., O`Toole, C.M. \& McCann, F. (2014). Does bank market power affect SME financing constraints? Journal of Banking \& Finance, 49, 495-505.

Sanfilippo-Azofra, S., Lopez-Guitierrez, C. \& Torre-Olmo, B. (2016). Coverage of financing deficit in firms in financial distress under the pecking order theory. E+M, Ekonomie a Management, 19(4), 104-115.

Sivak, R. \& Mikocziova, J. (2006). Teória a politika kapitálovej štruktúry podnikatel'ských subjektov. Bratislava, Slovak Republic: SPRINT vfra.

Vinczeova, M. \& Kristofik, P. (2013). Corporate finance. Banská Bystrica, Slovak Republic: Univerzita Mateja Bela Banská Bystrica, Ekonomická fakulta.

Vlachynsky, K. \& Kralovic, J. (2011). Finančný manažment. Bratislava, Slovak Republic: Iura Edition.

Zhang, H., Yang, F. \& Long, F. (2014). Credit crunch and target capital structure: Empirical studies based on natural experiment in China. Emerging Markets Finance \& Trade, 50(5), 229-244. 